\title{
BLOOD GROUP ANTIGENS ON HUMAN SPERMATOZOA
}

\author{
R. G. EDWARDS,* L. C. FERGUSON AND R. R. A. COOMBS \\ Division of Experimental Biology, National Institute for Medical Research, \\ London, N.W.7, and Department of Pathology, University of Cambridge
}

(Received 6th August 1963)

\begin{abstract}
Summary. Antigens on the membrane of human spermatozoa have been investigated using the mixed agglutination and mixed antiglobulin reactions. The spermatozoal membrane was shown to possess 'speciesspecific' antigens in common with red cells which probably correspond to antigens on other tissue cells of the body.

The A and B blood group iso-antigens have been shown on the spermatozoa of secretors but not on the spermatozoa of non-secretors. The presence of the iso-antigens $\mathrm{M}, \mathrm{N}$ and $\mathrm{Tja}$ was established; however, the sex-linked antigen Xga could not be shown on the spermatozoa.
\end{abstract}

\section{INTRODUCTION}

More than usual interest centres on the presence of blood group and other iso-antigens on human spermatozoa. Gene segregation at meiosis might lead to the production of spermatozoa of distinct phenotype, e.g. types A and B from an $A B$ heterozygote, which would permit extensive genetic studies on one sperm sample. Particular types of spermatozoa might then be selected from a sperm sample by means of refined immunological procedures. It should also be possible to study the interaction between antigens in seminal plasma with those on spermatozoa by using semen from secretors and non-secretors, for the former secrete $\mathrm{AB}$ and Lewis antigens into body fluids including seminal plasma. Finally, the detection of antigens in seminal plasma or on spermatozoa, whether displaying genetic segregation or not, could be of importance in studies on sterility. Differences in blood groups between husband and wife might lead to immunization of the wife through coitus, and perhaps result in sterility in some couples. In the present work we have examined human spermatozoa for blood group and other antigens by means of the mixed agglutination reaction (Coombs, Bedford \& Rouillard, 1956) and the mixed antiglobulin reaction (Coombs, Marks \& Bedford, 1956) which were evolved with the express purpose of studying blood group iso-antigens on tissue cells.

Several workers have studied human spermatozoa in relation to the presence of $\mathrm{ABO}$ or rhesus antigens, and have reported conflicting results. Landsteiner \& Levine (1926) used absorption techniques to demonstrate A and B antigens

\footnotetext{
* Present address: Physiological Laboratory, University of Cambridge.
} 
on human spermatozoa. At this date, it must be realized, the discrimination between the secretor and non-secretor status was not known. Levine \& Celano (1961) used similar techniques to detect A and B antigens on seminal spermatozoa from secretors and non-secretors. Gullbring (1957) applied the mixed agglutination reaction to human spermatozoa and detected both $\mathrm{A}$ and $\mathrm{B}$ and rhesus antigens, but gave no indication of the secretor status of the donors. Despite this Gullbring reported that in $A B$ persons the two blood factors segregated on separate spermatozoa. The question of the rhesus $D$ antigen on spermatozoa was extended by Majsky \& Hraba (1960). Using mixed agglutination, an adsorption technique and an absorption-elution technique, these authors concluded that the $\mathrm{D}$ antigen was present on human spermatozoa. Most recently Shahani \& Southam (1962) used immunofluorescence to detect specific A and B spermatozoa, and supported Gullbring's claims on the segregation of these antigens on separate spermatozoa.

Unfortunately each of these observations has been denied. Holborow, Brown, Glynn, Hawes, Gresham, O'Brien \& Coombs (1960) used immunofluorescence with potent rabbit anti-A sera but found no specific staining of testicular spermatozoa on four Group A adults and in sections of two infant testes. Levine \& Celano (1961) failed to detect the rhesus D antigen with an absorption-elution technique. With a long absorption there appeared to be a non-specific uptake. Quinlivan \& Masouredis (1962) measured the uptake of ${ }^{231}$ I-labelled anti-D and found no evidence for the presence of the $\mathrm{D}$ antigen on human seminal spermatozoa.

\section{MATERIALS AND METHODS}

\section{Glassware}

Except for the original container of the semen sample, siliconed glassware was used throughout.

\section{Diluents used for tests and for washing spermatozoa}

Bovine plasma albumin (crystalline), at a concentration of $0.02 \%$ in $0.9 \%$ sodium chloride solution buffered at $\mathrm{pH} 7.2$ with Sörensen's phosphate buffer, was ordinarily used for the diluent in the tests. During the course of this work various diluents were used for suspending and washing the spermatozoa. Early in the work $0.2 \%$ bovine plasma albumin in buffered saline was used; however, in the later tests Medium 199 and Hanks's solution were used with good results.

\section{Samples of spermatozoa}

Semen specimens were obtained from fertility clinics in Cambridge and London. The specimens were collected in dry vials and were usually available within $2 \mathrm{hr}$ after donation and after any clot formation had liquefied at $37^{\circ} \mathrm{C}$. One sample was collected from a spermatocoele.

\section{Preparation of suspension of spermatozoa for testing}

In initial tests the spermatozoa were centrifuged and washed at $4^{\circ} \mathrm{C}$, but subsequent tests were carried out at room temperature. 
The semen sample was centrifuged for $10 \mathrm{~min}$ at $2000 \mathrm{rev} / \mathrm{min}$ in an MSE bench centrifuge. The supernatant fluid was removed and the deposited cells resuspended in the diluent. Light centrifugation for $3 \mathrm{~min}$ at $500 \mathrm{rev} / \mathrm{min}$ was used to deposit clumps of spermatozoa and cellular debris. The supernatant suspension was again centrifuged at $2000 \mathrm{rev} / \mathrm{min}$ for 5 to $10 \mathrm{~min}$, and after removal of supernatant fluid the spermatozoa received one further washing. They were then resuspended to a convenient concentration and distributed to a series of tubes ready for testing.

Excessive centrifugation causes loss of motility of the spermatozoa and the amount and speed of centrifugation were therefore kept at the minimum required to sediment the spermatozoa. As the viscous elements of the seminal fluid were removed by washing, the speed or time of centrifugation was decreased slightly.

\section{Antisera}

Rabbit anti-human red-cell serum, rendered specific for identifying human tissue cells by mixed agglutination, was prepared as described by Coombs, Daniel, Gurner \& Kelus (1961) and was used at a 1/10 dilution.

Anti-A sera. Five different human anti-A sera $(2214,5044,1466, \mathrm{HA}$ and AD) were used. These had all been found satisfactory in mixed agglutination tests on human buccal mucosal cells. They were used at a $1 / 5$ dilution.

Anti-B sera. These (ST and 2934) were selected as were the anti-A sera. ST was from a Group A person and 2934 from a Group O person. These were also used diluted $1 / 5$.

Anti-M and anti- $\mathcal{N}$ sera. Rabbit antisera, prepared as for routine blood-typing, and giving specific reactions with red cells, were used undiluted.

Anti-Tja. A serum from a Tjb person, and having a titre against red cells of 8 to 16 , was used undiluted in the tests.

Anti-Xga. This was kindly supplied by Dr Cahan of Knickerbocker Biologicals, New York.

Human sera with sperm auto-antibodies. These were kindly sent to us by $\mathrm{Dr}$ Rümke of Amsterdam and were obtained from patients with oligo- or azoöspermia.

Anti-human globulin serum and incomplete anti-D serum. These were sera as used in routine antiglobulin tests.

All antisera were heat-inactivated at $56^{\circ} \mathrm{C}$ for half an hour before use.

\section{Blood typing of patients}

The $\mathrm{ABO}$ and $\mathrm{MN}$ groups were determined by standard typing procedures. The secretor status as regards the $\mathrm{ABO}$ system was determined by inhibition tests using saliva or the cell-free seminal plasma obtained after depositing the spermatozoa of the semen by centrifugation. There were no doubtful cases. There was either no inhibition with seminal fluid diluted $1 / 10$ or inhibition with a dilution of $1 / 50$ or greater. 
Indicator red cell suspension

For mixed agglutination. This consisted of a $0.5 \%$ suspension of three-timeswashed human red cells in diluent. The antigenic type depended on the test, i.e. either $\mathrm{A}, \mathrm{B}$ or $\mathrm{O}$ or $\mathrm{M}$ or $\mathrm{N}$. No $T j b / T j b$ cells were available to control the specificity of the Tja reactions.

For mixed antiglobulin. $1 \mathrm{ml}$ of $2 \%$ human $\mathrm{O} \mathrm{Rh}$ positive red cells were sensitized with $1 \mathrm{ml}$ of a $1 / 20$ dilution of human serum containing incomplete anti-D Rh antibody. After incubation the cells were washed three times in diluent and resuspended finally as a $0.5 \%$ suspension for the test.

\section{Mixed agglutination reaction}

The procedure was essentially the same as that described by Coombs, Bedford \& Rouillard (1956) except that the test was performed on live spermatozoa. The suspension of washed spermatozoa was lightly centrifuged and the supernatant removed. Antiserum was added directly to the deposited spermatozoa, which were then resuspended and incubated at room temperature for $1 \mathrm{hr}$ with gentle mixing.

The tubes were then centrifuged for 5 to $10 \mathrm{~min}$ at 1500 to $1800 \mathrm{rev} / \mathrm{min}$ to deposit the spermatozoa, the supernatant removed and replaced with 0.5 to $1 \mathrm{ml}$ of fresh diluent. After three such washings the spermatozoa were resuspended in one drop of diluent to which was added one drop of the indicator red-cell suspension. The tubes were again lightly centrifuged to bring the two cell types in contact. The deposited cells were then examined under a phasecontrast microscope, in a sealed coverslip preparation. Mixed agglutination between the red cells and spermatozoa, which were often still motile, could then be observed (P1. 1, Figs. 1 and 2).

\section{Mixed antiglobulin reaction}

This reaction has been fully described by Chalmers, Coombs, Gurner \& Dausset (1959), but a modification was introduced into the present work. The antiglobulin serum was added to the washed serum-treated spermatozoa and the excess washed away before adding the indicator red-cell system.

Briefly the steps were as follows. Serum was added to the deposited spermatozoa. After incubation, the spermatozoa were washed three times and antiglobulin serum at a dilution of $1 / 20$ was added. After reincubation for $15 \mathrm{~min}$, the spermatozoa were washed twice and resuspended in one drop of diluent. One drop of the indicator cell suspension was added, the tubes lightly centrifuged to bring the two cell types together, and the cells examined under the microscope. Positive mixed agglutination indicates that the spermatozoa had been sensitized by the antibody.

\section{RESULTS}

DEMONSTRATIONS BY MIXED AGGLUTINATION OF 'SPECIES-CHARACTERIZING' ANTIGENS ON HUMAN SPERMATOZOA COMMON TO RED CELLS

Suspensions of human spermatozoa were tested with a rabbit anti-human Group $\mathrm{O}$ red-cell serum previously rendered specific for the identification of 
human tissue culture cells as described by Coombs et al. (1961). Powerful mixed agglutination occurred between spermatozoa and the human Group $\mathrm{O}$ red cells. This antiserum caused no mixed agglutination with mouse spermatozoa.

This test demonstrated the occurrence of common antigenic determinants on red cells and on the outer membrane of the spermatozoa. The distribution of these antigens seemed to be universal on the sperm membrane as the reaction was equally strong over the head and along the tail. The antigens measured are probably the same as those revealed with the use of this serum on many tissues of the human body and on all the human cells grown in tissue culture so far tested (see Franks, Gurner, Coombs \& Stevenson, 1962). The human spermatozoa gave no reaction with anti-rat or anti-mouse red-cell sera and the corresponding rat and mouse indicator red cells.

TABLE 1

BLOOD GROUP ANTIGENS A, B, M, N AND TJA ON HUMAN SPERMATOZOA

\begin{tabular}{|c|c|c|c|c|c|c|}
\hline \multirow{2}{*}{ Specimen } & \multirow{2}{*}{ Blood type } & \multicolumn{5}{|c|}{ Antigens shown by mixed agglutination } \\
\hline & & $A$ & $B$ & $M$ & $\mathcal{N}$ & Tja \\
\hline $\begin{array}{l}\quad 4900 \\
\text { Spermatocoele } \\
\text { Cam BS } \\
\text { Lon Y } \\
989 \\
9972\end{array}$ & $\begin{array}{l}A_{1} M \text { secretor } \\
A_{1} M \text { secretor } \\
A_{1} M \text { secretor } \\
A_{1} \text { secretor } \\
A_{1} B M N \text { secretor } \\
B N \text { secretor }\end{array}$ & $\begin{array}{l}+ \\
+ \\
+ \\
+ \\
+ \\
+\end{array}$ & - & $\begin{array}{l}+ \\
+ \\
+ \\
+ \\
w\end{array}$ & $\begin{array}{l}- \\
- \\
w \\
w\end{array}$ & $\begin{array}{l}w \\
w \\
w\end{array}$ \\
\hline $\begin{array}{r}806 \\
14564 \\
\text { Lon G } \\
\text { Lon } 2 / 8\end{array}$ & $\begin{array}{l}\mathrm{A}_{1} \mathrm{MN} \text { non-secretor } \\
\mathrm{A}_{2} \mathrm{MN} \text { non-secretor } \\
\mathrm{A}_{2} \text { non-secretor } \\
\mathrm{B} \text { non-secretor }\end{array}$ & $\begin{array}{l}- \\
- \\
-\end{array}$ & $\begin{array}{l}- \\
- \\
-\end{array}$ & $\begin{array}{l}w \\
+\end{array}$ & $\begin{array}{l}\mathbf{w} \\
\mathbf{w}\end{array}$ & $w$ \\
\hline $\begin{array}{r}\text { Lon } W_{705} \\
3502 \\
3363\end{array}$ & $\begin{array}{l}\mathrm{O} \\
\mathrm{O} \mathrm{M} \\
\mathrm{O} \\
\mathrm{O}\end{array}$ & $\begin{array}{l}- \\
- \\
-\end{array}$ & $\begin{array}{l}- \\
- \\
-\end{array}$ & $\begin{array}{l}+ \\
+ \\
-\end{array}$ & $\begin{array}{l}- \\
w \\
w\end{array}$ & $\begin{array}{l}w \\
w \\
w\end{array}$ \\
\hline
\end{tabular}

\section{EXAMINATION OF HUMAN SPERMATOZOA FOR BLOOD GROUP ISO-ANTIGENS BY MIXED AGGLUTINATION}

For mixed agglutination it is necessary to have fairly powerful agglutinating sera and in the tests for the $\mathrm{A}, \mathrm{B}, \mathrm{M}, \mathrm{N}$ and Tja iso-antigens which are now reported, sera were used which had been found to be satisfactory in mixed agglutination tests on other tissue cells.

Over forty samples of seminal spermatozoa and one sample of spermatozoa from a spermatocoele have been tested. Representative results together with the blood type and secretor status are given in Table 1.

With the $A B O$ system it can be seen that in secretors of the blood group substances the washed spermatozoa reacted according to the blood type. In non-secretors, however, (nine samples tested) it was not possible to show the 
corresponding antigen on the spermatozoa. The indicator red cells showed no affinity for the serum-treated spermatozoa, yet a strong positive reaction was found around the numerous other tissue cells in the preparation. This latter finding, in fact, formed a good control for the test itself.

The $\mathbf{M}$ and $\mathbf{N}$ antigens were shown unequivocally to be present on the spermatozoa. The reaction with $\mathrm{M}$ was fairly strong while with $\mathrm{N}$ the reaction was much weaker, but nevertheless definite. With one sample (No. 9972) a weak reaction with anti-M was obtained on a patient grouped as $\mathrm{N}$. Again although the reaction with anti-Tja was weak it was quite definite and as would be expected all samples tested were positive. With these three antigen systems both the head and tail of the spermatozoa were involved in the reactions.

USE OF THE MIXED ANTIGLOBULIN REACTION TO DEMONSTRATE ANTIGENS FOR WHICH ONLY NON-AGGLUTINATING ANTIBODY REAGENTS ARE AVAILABLE

It was of great interest to determine whether the sex-linked antigen Xga (Mann, Cahan, Gelb, Fisher, Hamper, Tippett, Sanger \& Race, 1962) was present on spermatozoa. Since the antibody, anti-Xga, requires an antiglobulin reaction to demonstrate its combination with cells, a mixed antiglobulin system was used.

To control the effectiveness of the mixed antiglobulin reaction to reveal sensitization of human spermatozoa with human antibody, mixed antiglobulin tests were performed on spermatozoa exposed to normal human sera (control) and to human sera containing sperm auto-antibodies (Rümke, 1959). After washing the serum-treated spermatozoa they were exposed to an anti-human globulin serum and again washed. On mixing these spermatozoa with a suspension of human red cells sensitized with human incomplete $\mathrm{Rh}$ antibody, a powerful mixed agglutination resulted in the sperm samples treated with autoantibodies. No mixed agglutination occurred with the sperm samples treated with normal human serum. This showed that human spermatozoa do not absorb human $\gamma$-globulin non-specifically and that sensitization with human antibody can be revealed by the mixed antiglobulin reaction.

Testing spermatozoa from two Xga positive persons with anti-Xga by this method gave a negative result suggesting that this antigen is not present on the membrane of spermatozoa.

\section{DISCUSSION}

The present results have shown that, in our hands, mixed agglutination and mixed antiglobulin are useful techniques for the investigation of the antigens, and especially the isoantigens, on human spermatozoa. Positively and negatively reacting sera have shown the feasibility of both testing procedures. By performing the tests on live spermatozoa there is a 'built in' mixing system and mixed agglutination can be detected very easily, for the spermatozoa remain motile even when covered with red cells. Cell types other than spermatozoa are often very plentiful in some sperm samples (Pl. 1, Figs. 3 and 4), and reactions involving these cells serve as an excellent control. This point was strikingly 
patent in tests for A and B in non-secretors, where non-spermatozoal cells reacted strongly although the spermatozoa showed no mixed agglutination. The use of absorption or absorption and elution techniques on sedimented cellular deposits from semen must therefore be questioned.

Our findings show that the $\mathbf{M}, \mathbf{N}$ and Tja antigens are on the spermatozoal membrane as they are on platelets and leucocytes (Gurner \& Coombs, 1958). In secretors we infer that $\mathrm{AB}$ antigens in seminal plasma (Friedenreich \& Hartmann, 1938) adhere secondarily to spermatozoa, and are not removed by three washings. The firmness with which Substance A can be adsorbed on to tissue cells is shown in experiments on buccal epithelial cells where even ten washes failed to remove the adsorbed antigen (Swinburne, Frank \& Coombs, 1961).

We were unable to detect the A and B antigens on spermatozoa from nonsecretors, and so disagree with the results of other workers (Gullbring 1957; Popivanov \& Vulchanov, 1962). We also view with caution the observations of Shahani \& Southam (1962) who used immunofluorescence to detect AB antigens on human spermatozoa from secretors and non-secretors. It is possible, however, that immunofluorescence detects antigens that are deep-seated in the spermatozoal membrane and are not detectable by mixed agglutination.

As mentioned in the introduction, genetic segregation at meiosis might lead to the production of spermatozoa carrying individual antigens. Extensive genetic studies would then be possible on spermatozoa in a single ejaculate. Failure to detect the $\mathrm{AB}$ antigens excludes using the genes at this locus, but our results suggest that the $\mathrm{MN}$ antigens and Tja might be useful. In this connexion it is disappointing that Xga was not detectable on spermatozoa. This gene is sex-linked (Mann et al., 1962); segregation might have resulted in spermatozoa with an $\mathrm{X}$ chromosome carrying the antigen, and those with a $\mathrm{Y}$ chromosome lacking it. As this antigen is carried by more than $60 \%$ of men, it might have served as a means of controlling the primary sex ratio in man. We intend to extend these studies to further isoantigen systems. We are inclined to accept the findings of Quinlivan \& Masouredis (1962) and Levine \& Celano (1961) that the rhesus $\mathrm{D}$ antigen is absent from spermatozoa (see Introduction), since we also find this antigen to be absent from leucocytes (Gurner \& Coombs, 1958).

$\mathrm{AB}$ incompatibility between husband and wife has been implicated in cases of partial infertility or gametic selection (e.g. Matsunaga \& Hiraizumi, 1962; Behrman, Buettner-Janusch, Heglar, Gershowitz \& Tew, 1960). From our present results, any incompatibility must be due to antigens in the seminal plasma and therefore related to the secretor status of the husband. It was of interest that $A B$ antigens were detected on spermatozoa from the spermatocoele of a secretor. These antigens must be present in the upper part of the reproductive tract in addition to seminal plasma. Human spermatocoele spermatozoa have been reported not to induce antibodies when injected into guinea-pigs or rabbits (Weil \& Rodenburg, 1960). It is surprising that human spermatozoa should fail to elicit an immune reaction across a species barrier, especially when we could detect on them three isoantigens and antigen(s) shared with human erythrocytes and tissue cells. In rabbits the major antigens in semen are present 
in seminal plasma and become attached firmly to spermatozoa (Weil, 1960). Antigens are evidently present on rabbit spermatozoa since those from the epididymis were agglutinated by auto-antibodies against semen (Edwards, 1960).

Living human spermatozoa failed to adsorb human $\gamma$-globulin nonspecifically. With fixed spermatozoa, a weak reaction between human spermatozoa and $\gamma$-globulin from several species is detectable by immunofluorescence in the acrosome (Beck, Edwards \& Young, 1962). The different results of the two experiments might be due to changes in the spermatozoa induced by fixation in alcohol, which evidently modifies the acrosomal structure (Abraham \& Bhargava, 1963).

\section{ACKNOWLEDGMENTS}

Grants from the American Cancer Society (to L. C. F. as Scholar in Cancer Research) and from the National Institutes of Health, Bethesda, U.S.A. (R. R. A. G.) are gratefully acknowledged. We would like to thank Dr Rümke of Amsterdam and Dr Cahan of New York for the sperm auto-antibodies and Xga serum respectively, and Dr R. R. Race, F.R.s., for grouping some donors. We wish to acknowledge the most helpful co-operation of $\mathrm{Mr} \mathrm{O}$. Lloyd and Miss J. Bottomley of the Department of Obstetrics and Gynaecology, Addenbrooke's Hospital, of Dr M. H. Gleeson-White and Mr P. W. Powles of the John Bonnett Clinical Laboratories, Addenbrooke's Hospital and $\mathrm{Dr} \mathbf{H}$. Onions, University College Hospital, for allowing us to study semen samples from the Fertility Clinic. We also thank Mr J. Withycombe of the Department of Surgery, Addenbrooke's Hospital for the spermatocoele specimen.

\section{REFERENCES}

Abraham, K. A. \& Bhargava, P. M. (1963) The uptake of radioactive amino acids by spermatozoa. The intracellular site of incorporation into proteins. Biochem. 7. 86, 308.

Beck, J. S., Edwards, R. G. \& Young, M. R. (1962) Immune fluorescence technique and the isoantigenicity of mammalian spermatozoa. F. Reprod. Fertil. 4, 103.

Behrman, S. J., Buettner-Janusch, J., Heglar, R., Gershowitz, H. \& Tew, W. L. (1960) ABO(H) blood incompatibility as a cause of infertility: a new concept. Amer. F. Obstet. Gynec. 79, 847.

Ghalmers, D. G., Coombs, R. R. A., Gurner, B. W. \& Dausser, J. (1959) The mixed antiglobulin reaction in the detection of human isoantibodies against leucocytes, platelets and HeLa cells. Brit. 7. Haemat. 5, 225.

Coombs, R. R. A., Bedford, D. \& Rouillard, L. M. (1956) A and B blood group antigens on buman epidermal cells. Lancet, i, 461 .

Coombs, R. R. A., Daniel, M. R., Gurner, B. W. \& Kelus, A. (1961) Recognition of the species of origin of cells in culture by mixed agglutination. I. Use of antisera to red cells. Immunology, 4, 55 .

Coombs, R. R. A., MARKs, J. \& BEDFord, D. (1956) Specific mixed agglutination: mixed erythrocyteplatelet antiglobulin reaction for the detection of platelet antibodies. Brit. 7. Haemat. 2, 84.

Edwards, R. G. (1960) Antigenicity of rabbit semen, bull semen and egg yolk after intravaginal or intramuscular injections into female rabbits. F. Reprod. Fertil. 1, 385.

Franks, D., Gurner, B. W., Coombs, R. R. A. \& Stevenson, R. (1962) Results of tests for the species of origin of cell lines by means of the mixed agglutination reaction. Exp. Cell Res. 28, 608.

Friedenreich, V. \& Hartmann, G. (1938) Ueber die Verteiling der Gruppenantigene im Organismus der sogenannten "Ausscheider" und "Nichtausscheider". Z. ImmunForsch. 92, 141.

GulldBring, B. (1957) Investigation on the occurrence of blood group antigens in spermatozoa from man and serological demonstration of the segregation of characters. Acta med. scand. 159, 169. 
PLATE 1

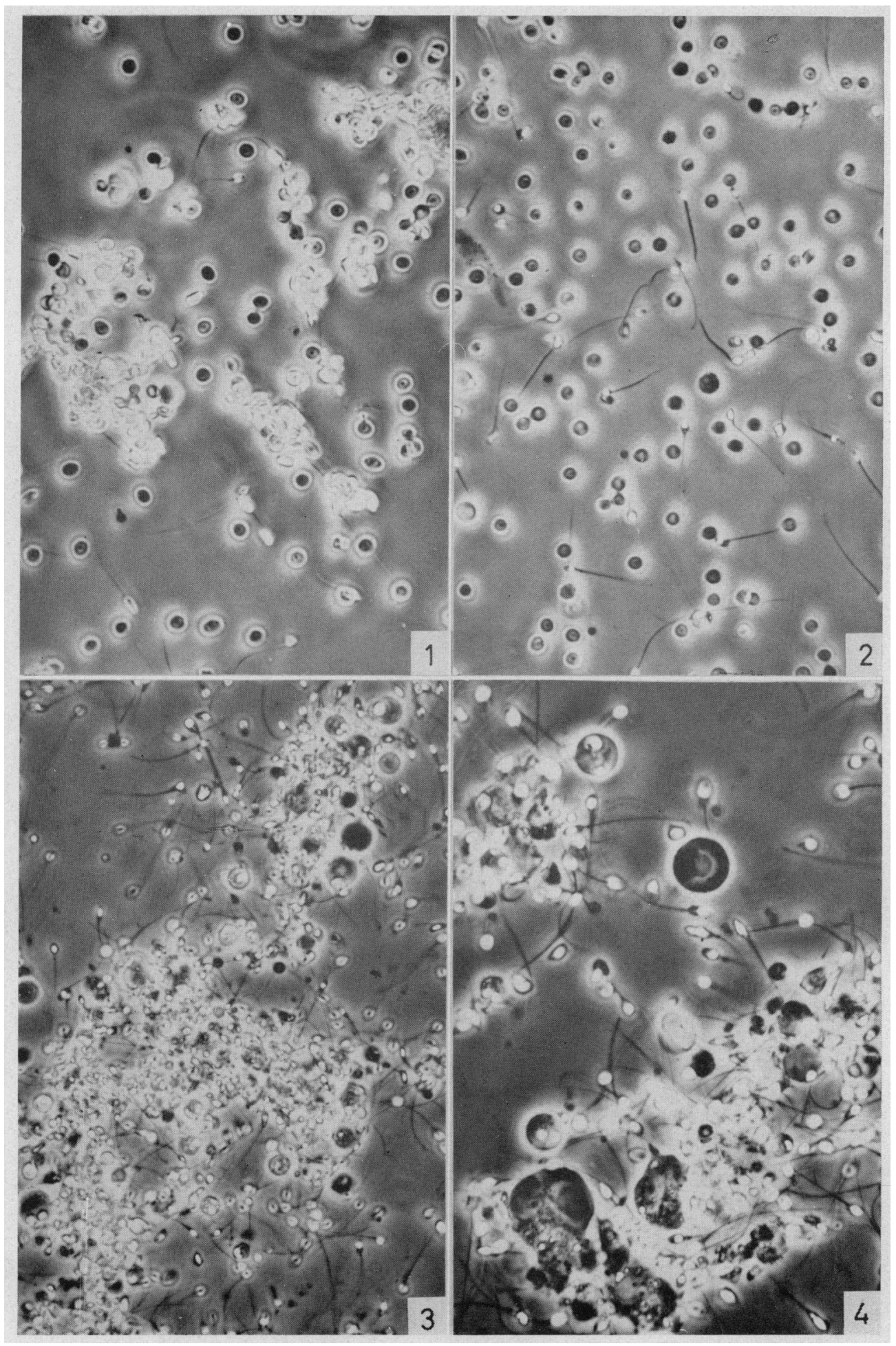

(Facing f. 161) 
Gurner, B. W. \& Coombs, R. R. A. (1958) Examination of human leucocytes for the ABO, MN, Rh, Tja, Lutheran and Lewis systems of antigens by means of mixed erythrocyte-leucocyte agglutination. Vox Sang. 3, 13.

Holborow, E. J., Brown, P. G., Glynn, L. E., Hawes, M. D., Gresham, G. A., O’Brien, T. F. \& Coomss, R. R. A. (1960) The distribution of the blood group A antigen in human tissues. Brit. $\mathcal{Z}$. exp. Path. 41, 430.

Landsteiner, K. \& Levine, P. (1926) On group specific substances in human spermatozoa. F. Immunol. $12,415$.

Levine, P. \& Celano, M. J. (1961) The question of $\mathrm{D}\left(\mathrm{Rh}_{0}\right)$ antigenic sites on human spermatozoa. Vox Sang. 6, 720.

MAJSKx, A. \& HrABA, T. (1960) Demonstration of $\mathrm{D}\left(\mathbf{R} \mathbf{h}_{0}\right)$ agglutinogens in human spermatozoa. Folia biol. 6, 342.

Mann, J. D., Gahan, A., Gelb, A. G., Fisher, N., Hamper, J., Tippett, P., Sanger, R. \& Race, R. R. (1962) A sex-linked blood group. Lancet, i, 8.

Matsunaga, E. \& Hiraizumi, Y. (1962) Prezygotic selection in ABO blood groups. Science, $135,432$.

Popivanov, R. \& Vulchanov, V. H. (1962) Segregation of man's AB group spermatozoa in A- and B-spermatozoa through agglutination with immune anti-A rabbit serum. Z. ImmunForsch. 124, 206.

Quinlivan, W. L. G. \& Masouredis, S. P. (1962) Rho (D) antigen content of human spermatozoa. Immunology, 5, 267.

Rümke, PH. (1959) Auto-antilichamen legen spermatogoen als ooryaak van onvruchtbaarkeit bÿ de man. Doctorate thesis, University of Amsterdam.

SHahan, S. \& Southam, A. L. (1962) Immunofluorescent study of the ABO blood group antigens in human spermatozoa. Amer. F. Obstet. Gynec. 84, 660.

Swinburne, L. M., Frank, B. B. \& Coombs, R. R. A. (1961) The A antigen on the buccal epithelial cells of man. Vox Sang. 6, 274.

WEIL, A. J. (1960) Immunological differentiation of epididymal and seminal spermatozoa of the rabbit. Science, 131, 1040.

WeIL, A. J. \& Rodenburg, J. M. (1960) Immunological differentiation of human testicular (spermatocele) and seminal spermatozoa. Proc. Soc. exp. Biol., N.r. 105, 43.

\section{EXPLANATION OF PLATE 1}

Fig. 1. Positive result: mixed agglutination between spermatozoa and indicator red cells. Phase-contrast microscopy, $\times 10$ eyepiece, $\times 25$ objective.

FIG. 2. Negative result: mixed agglutination reaction. No affinity between antiserumtreated spermatozoa and indicator red cells. Phase-contrast microscopy, $\times 10$ eyepiece, $\times 25$ objective.

Frgs. 3 and 4. Tissue cells and cellular debris together with spermatozoa in centrifugal deposit of human ejaculated semen. Phase-contrast microscopy. Fig. 3: $\times 10$ eyepiece, $\times 25$ objective. Fig. $4: \times 10$ eyepiece, $\times 40$ objective. 